Finding valuable bioactive components from Jerusalem artichoke (Helianthus tuberosus L.) leaf protein concentrate in a green biorefinery concept

\author{
László Kaszás ${ }^{a^{*}}$, Tarek Alshaal ${ }^{\mathrm{a}, \mathrm{b}}$, Hassan El-Ramadya,b, Zoltán Kovács ${ }^{\mathrm{a}}$, Judit Koroknai ${ }^{\mathrm{a}}$, \\ Nevien Elhawata,c, Éva Nagya ${ }^{a}$ Zoltán Cziáky; Miklós Fária, Éva Domokos-Szabolcsya \\ a Agricultural Botany, Plant Physiology and Biotechnology Department, University of Debrecen,
} Debrecen, Hungary (kaszas.laszlo@agr.unideb.hu; kovacs.zoltan@agr.unideb.hu; nagyeva0116@gmail.com; fari@agr.unideb.hu;

\title{
koroknaij@agr.unideb.hu; szabolcsy@agr.unideb.hu)
}

${ }^{b}$ Soil and Water Department, Faculty of Agriculture, University of Kafrelsheikh, Kafr El-Sheikh, Egypt(ramady2000@gmail.com; alshaaltarek@gmail.com)

${ }^{c}$ Department of Biological and Environmental Sciences, Faculty of Home Economic, Al-Azhar University,Egypt(nevienelhawat@gmail.com)

d Agricultural and Molecular Research and Service Institute, University of Nyíregyháza, Nyíregyháza, Hungary (cziaky.zoltan@nye.hu)

* Corresponding author: László Kaszás, University of Debrecen, Debrecen, Hungary; E-mail address: kaszas.laszlo@agr.unideb.hu

\section{Abstract}

Jerusalem artichoke is widely known for its inulin-enriched tubers. Recently the opportunity has been arisen to involve the whole plant in biorefinery concept due to its high lignocellulose biomass and tuber production. This paper focuses on the repeatedly harvestable green biomass of Jerusalem artichoke. Ultra-High Performance Liquid Chromatography-Electrospray Ionization/Mass Spectrometry (UHPLC-ESI-MS) was applied to identify the phytochemicals in Jerusalem artichoke leaf protein concentrate (JAPC) thermally extracted from green biomass of three clones, i.e., Alba, Fuseau and Kalevala. Amino acid and fatty acid profiles as well as yield of JAPC were also analyzed. The UHPLC-ESI-MS analyses showed that no toxic phytochemicals were identified in JAPC. The results revealed, also, that JAPC is not only essential-amino acidsrich but also contains substantial amounts of polyunsaturated fatty acids (66-68\%) such as 
linolenic and linoleic acids. Linolenic acid represented 39-43\% of total lipid content; moreover,

31 the ratio between $\omega-6$ and $\omega-3$ essential fatty acids in JAPC was $\sim 0.6: 1$. Using UHPLC-ESI-MS,

32 the following hydroxylated methoxyflavones were for the first time identified in JAPC, i.e.,

33 dimethoxy-tetrahydroxyflavone, dihydroxy-methoxyflavone, hymenoxin and nevadensin. These

34 compounds are medically important since they are referred to as anti-cancer, anti-inflammatory

35 and antioxidants. Also, liquiritigenin - estrogenic-like compound - was identified in JAPC

36 alongside the following terpenes, i,e., loliolide and dihydroactinidiolide. However, no remarkable

37 differences of phytochemicals, fatty acids and amino acids composition were seen among

38 Jerusalem artichoke clones. The green biomass of tested clones ranged between 5 to $5.6 \mathrm{~kg} \mathrm{~m}^{-2}$

39 and JAPC yield varied from 28.6 to $31.2 \mathrm{~g} \mathrm{DM} \mathrm{kg}^{-1}$ green biomass with total protein content, on

40 average, of $33.3 \%$. According to our knowledge, this paper is the first scientific report

41 highlighting bioactive substances in JAPC such as PUFA phytochemicals. These results clearly

42 prove that JAPC is a valuable product which can direct towards human and animal nutrition as

43 well as it can serve as basic material for different industrial purposes.

44 Keywords: Jerusalem artichoke; leaf protein concentrate; polyunsaturated fatty acids;

$$
\text { phytochemicals; amino acids;; UHPLC-ESI-MS }
$$

\section{Introduction}

47 Ensuring an adequate supply of protein has become one of the challenges facing the world today,

48 which is expected to worsen in the future as a result of the terrible increase in population and the

49 erosion of agricultural land. The global protein supply relies on vegetal sources (57\%), meat

$50(18 \%)$, dairy products $(10 \%)$, fish and shellfish $(6 \%)$ and other animal products $(9 \%)$,

51 respectively [1]. Depending on species different organs of plants can serve as protein source such 
52 as seed (e.g. soy; pea; almond; pea; rice; wheat as seed-based protein), fruit (e.g. cranberry fruit-

53 based protein), leaf (e.g. moringa leaf-based protein) and root (e.g. maca root-based protein)

$54[2,3]$. Recently, leaf-based protein has gained an intensive attention. Alfalfa and grasses are the

55 most perspective species in continental climate zone. Alfalfa protein-xanthophyll concentrate

56 (APC) is an extensively studied processed product of fractionated green biomass. It has already

57 manufactured in different countries such as France for feed and food purposes $[4,5]$.

58 In context to leaf-based protein, the concept of green biorefineries is not be bypassed. Green

59 biorefineries are novel technology systems for production of materials and energy processing

60 using parts or total green plants [6]. Above all, green biorefinery technologies are based on

61 traditional technologies of green forage preservation, leaf-protein extraction, chlorophyll

62 production, and modern biotechnological and chemical conversion methods $[6,7,8,9]$. Sugar beet,

63 clover, alfalfa and grass are the most common and perspective species for green biorefinery

64 purposes in continental climate zone. However, several other crops may also be suitable.

65 Jerusalem artichoke can grow normally under harsh conditions [10,11]. It is tolerant to many

66 biotic and abiotic stresses such as pests and diseases [12], saline and alkaline soils, poor and

67 sandy soils with nearly zero fertilizer requirements [13], marginal lands [10], drought and high

68 temperature without interfering with other commercial crops as well [14]. Another important

69 advantage of Jerusalem artichoke, in comparison with the other fodder crops, is its ability to

70 produce huge green biomass under low input conditions (about 120 tons ha-1 fresh weight) [15].

71 This is an important aspect to avoid competition with the production of food in arable lands [16].

72 The nutritional value of Jerusalem artichoke is mainly due to the high inulin and fructose content

73 of sweetish tubers. Tuber, also, contains protein, nutrients and vitamins; therefore, it is valuable

74 for animal feeding and human consumption [16]. Although the aerial part of Jerusalem artichoke 
75 has widely gained the attraction of many researchers for bioethanol production due to its

76 lignocellulose content $[12,17]$, it can be directed towards other significant uses such as animal

77 feeding as fresh forage, silage, or food pellets [16]. In addition, there are some information about

78 green leafy shoot which contain protein (stalk: $1.6 \%-4.5 \% \mathrm{DW}$; leaves $7.1 \%-24.5 \%$ DW),

79 volatile sesquiterpenes, some phenolic compounds, chlorophylls, carotenoids $[11,17,18]$.

80 However, direct consumption of fresh or dried Jerusalem artichoke biomass is not preferable

81 because trichomes covered leaves and stem [11]. Alternatively, green biomass can be fractionated

82 mechanically to green juice and fiber fractions. The cell wall-deprived green juice can be

83 thermally treated in order to extract proteins by coagulation. From the aspect of green biorefinery

84 the separate leaf protein concentrate as main product has special importance hence to become

85 competitive process it should produce at least one product of high value (such as a high value

86 chemical or material).

87 In accordance with the above, the present study aimed to provide a detailed insight into the

88 extraction efficiency and biochemical composition of green biomass originated Jerusalem

89 artichoke leaf protein concentrate (JAPC). Three clones of Jerusalem artichoke representing

90 different climatic zones were grown under low input conditions in Hungary. Biochemical

91 composition and qualitative determination of phytochemicals in JAPC were conducted via Ultra-

92 High Performance Liquid Chromatography-Electrospray Ionization/Mass Spectrometry

93 (UHPLC-ESI-MS).

94 Materials and Methods

95 Experimental installation 
A field experiment was conducted in 2016 at the Horticultural Demonstration garden of the University of Debrecen, Hungary (473’N; $\left.21^{\circ} 36^{\prime} \mathrm{E}\right)$. Three different clones of Jerusalem artichoke (i.e., Alba, Fuseau and Kalevala) were compared for their fresh aerial biomass yield, JAPC and phytochemical composition under low input conditions. Tubers of Jerusalem artichoke clones representing three climatic zones were obtained from different sources as follow: Alba was brought from Hungarian market; Fuseau was brought from Ismailia, Egypt; and Kalevala was obtained from Helsinki, Finland. The experiment was set up in a randomized complete block design with six replicates. The area of the experimental plot was $0.8 \times 0.6 \mathrm{~m}^{2}$; the row was $3.5 \mathrm{~m}$ in length and $0.8 \mathrm{~m}$ in width within-row spacing $0.6 \mathrm{~m}$. The cultivation of the Jerusalem artichoke clones started on $5^{\text {th }}$ April 2016 using size-identical tubers $(60-80 \mathrm{~g} /$ tuber $)$. No irrigation and fertilization were applied in the plantation during the growing season. Chemical characteristics of the experimental soil were: total $\mathrm{N}\left(555 \pm 2 \mathrm{mg} \mathrm{kg}^{-1}\right)$; total $\mathrm{P}\left(6793 \pm 17 \mathrm{mg} \mathrm{kg}^{-1}\right)$; total $\mathrm{K}(1298 \pm 7$ $\left.\mathrm{mg} \mathrm{kg}{ }^{-1}\right)$ and humus $(1.9 \pm 0.02 \%)$.

\section{Harvest of aboveground fresh biomass}

Considering the re-growing ability of Jerusalem artichoke plants, the green biomass of the three clones was harvested two times during the growing season when young shoot reached $1.3-1.5 \mathrm{~m}$ height from soil surface. The first harvest was carried out on $27^{\text {th }}$ June 2016, while the second harvest was on $8^{\text {th }}$ August 2016. Fresh yield of aerial part was measured.

\section{Fractionation of harvested green biomass}

The harvest of Jerusalem artichoke plants was carried out in the early morning and immediately transferred to the laboratory in an ice box to inhibit the degradation chemical compounds. Plants were harvested $20 \mathrm{~cm}$ above soil surface. One-kilogram green biomass was mechanically 
pressed and pulped by a twin-screw juicer (Green Star GS 3000, Anaheim, Canada) to green juice and fiber fractions in three replicates. Thereafter, the green juice was thermally coagulated at 80 ${ }^{\circ} \mathrm{C}$ to obtain JAPC. The JAPC was separated from brown-colored liquid fractions using cloth filtration. Both fresh and dry masses of JAPC were weighted. The JAPC was lyophilized using the Alpha 1-4 LSC Christ lyophilizer.

\section{Biochemical composition of JAPC}

\section{Crude protein content}

Total protein content of JAPC was measured as total $\mathrm{N}$ content by Kjeldahl method [19] as

follows: one gram lyophilized sample was weighted in a $250 \mathrm{~mL}$ Kjeldahl digestion tube and then

Kjeldahl digestion tubes were transferred to Tecator Digestor (VELT, VWR Ltd.) at $420^{\circ} \mathrm{C}$ for

$=$ total $\mathrm{N}$ content $\times 6.25$.

\section{Quantification of amino acid composition in JAPC by Amino acid analyzer}

134 For the sample preparation lyophilized and grinded sample of JAPC was digested with $6 \mathrm{M} \mathrm{HCl}$ measured weight of the samples was variable. For removing the air from the samples inert gas and vacuum alternating with applying a three-way valve were used. After hydrolyzing, the sample was filtered into evaporator flask. The filtrate was evaporated under $60^{\circ} \mathrm{C}$ to achieve 
again using the same circumstances. This procedure was repeated one more time. The evaporated sample was washed and completed with citrate buffer $\mathrm{pH}$ 2.2. For the analysis of amino acid composition INGOS AAA500 (Ingos Ltd., Czech Republic) Amino Acid Analyzer was used. The method of separation based on ionic exchange chromatography with postcolumn derivatization of ninhydrine. UV/VIS detector was used on 440/570 nm.

\section{Determination of fatty acid composition in JAPC by Gas Chromatography}

Esterification of fatty acids in JAPC fraction into methyl esters was conducted using sodium

156 Supelco Omegawax capillary column (30 m, $0.32 \mathrm{~mm}$ i.d., $0.25 \mu \mathrm{m}$ film thickness) was used to

157 separate FAMEs. The oven temperature was $180{ }^{\circ} \mathrm{C}$ and total analysis time was 36 min. An

158 Agilent 7683 automatic split/splitless injector was used with $280{ }^{\circ} \mathrm{C}$ injector temperature and 


\section{Sample preparation}

164 For the hydro-alcoholic extracts $0.5 \mathrm{~g}$ grinded JAPC powder was used and extraction was done by $25 \mathrm{~mL}$ methanol:water solution at ratio of $7: 3$. The mixture was stirred on $150 \mathrm{rpm}$ for $2 \mathrm{~h}$ at room temperature. The hydro-alcoholic extracts were filtered using a $0.22 \mu \mathrm{m}$ PTFE syringe 167 filter.

\section{UHPLC-ESI-MS analysis}

169 The phytochemical analyses were performed by UHPLC-ESI-MS (Ultra-High Performance 170 Liquid Chromatography-electrospray ionization/mass spectrometry) technique using a Dionex 171 Ultimate 3000RS UHPLC system (Thermo Fisher, USA) coupled to a Thermo Q Exactive 172 Orbitrap hybrid mass spectrometer equipped with a Thermo Accucore C18 analytical column (2.1 $173 \mathrm{~mm} \times 100 \mathrm{~mm}, 2.6 \mu \mathrm{m}$ particle size). The flow rate was maintained at $0.2 \mathrm{~mL} / \mathrm{min}$. The column 174 oven temperature was set to $25^{\circ} \mathrm{C} \pm 1{ }^{\circ} \mathrm{C}$. The mobile phase consisted of methanol (A) and water 175 (B) (both were acidified with $0.1 \%$ formic acid). The gradient program was as follows: 0 - 3 min, $17695 \% \mathrm{~B} ; 3-43 \mathrm{~min}, 0 \% \mathrm{~B} ; 43-61 \mathrm{~min}, 0 \% \mathrm{~B} ; 61-62 \mathrm{~min}, 95 \% \mathrm{~B} ; 62-70 \mathrm{~min}, 95 \% \mathrm{~B}$. The 177 injection volume was $2 \mu \mathrm{L}$.

\section{Mass spectrometry (MS) conditions}

179 Thermo Q Exactive Orbitrap hybrid mass spectrometer (Thermo Fisher, USA) was equipped with 180 an electrospray ionization (ESI) source. The samples were measured in positive and negative 181 ionization mode separately. Capillary temperature: $320{ }^{\circ} \mathrm{C}$. Spray voltage: $4.0 \mathrm{kV}$ in 182 positive ionization mode and $3.8 \mathrm{kV}$ in negative ionization mode, respectively. Resolution: 18335,000 in the case of MS1 scans and 17,500 in the case of MS2 scans. 100-1500 m/z 184 was the scanned mass interval. For MS/MS scans the collision energy was 
set to 30 NCE. The difference between measured and calculated molecular ion masses was less than 5 ppm in every case. The data were acquired and processed using Thermo Trace Finder 2.1 software based on own and internet databases (Metlin, Mass Bank of North

188 America, $\mathrm{m} / \mathrm{z}$ Cloud). After processing the results were manually checked using Thermo

Xcalibur 4.0 software. The compounds found in the extracts were identified on the basis our previous published works or data found in literature using exact molecular mass, isotopic pattern,

191 characteristic fragment ions and retention time.

\section{Quality assurance of results}

193 Glassware and plastic ware for analyses were usually new and were cleaned by soaking in $10 \%$ $194(\mathrm{v} / \mathrm{v}) \mathrm{HNO}_{3}$ for a minimum of $24 \mathrm{~h}$, followed by thorough rinsing with distilled water. All 195 chemicals were analytical reagent grade or equivalent analytical purity. All the used equipment 196 was calibrated and uncertainties were calculated. Internal and external quality assurance systems 197 were applied in the Central Laboratory of the University of Debrecen according to MSZ EN ISO 5983-1: 2005 (for Total N) and Bunge Private Limited Company Martfü Laboratory MSZ 190

199 5508: 1992 (for fatty acid composition).

\section{Statistical analysis}

201 The experimental design was established as a randomized complete block design with six.

202 Results of the experiments were subjected to one-way ANOVA by 'R-Studio' software and the 203 means were compared by Duncan's Multiple Range Test at $p<0.05$ [20].

\section{Results}

\section{Green biomass of Jerusalem artichoke clones}


Results of aboveground fresh biomass yield presented in Table 1. It is showed that the yield of Jerusalem artichoke clones were similar. No significant differences among tested clones (i.e., Alba, Fuseau and Kalevala) were noticed especially during the $1^{\text {st }}$ harvest. By contrast, the harvesting time influenced the yield. Significant lower yield could be harvested at the second harvest time. The average fresh biomass yield was approximately $5.3 \mathrm{~kg} \mathrm{~m}^{-2}$ in the $1^{\text {st }}$ harvest,

211 while in the $2^{\text {nd }}$ harvest the yield significantly reduced as the average biomass was $2.4 \mathrm{~kg} \mathrm{~m}^{-2}$ 212 (Table 1). The calculated total aboveground fresh biomass yield - as an average - was estimated to be $7.7 \mathrm{~kg} \mathrm{~m}^{-2}$.

Table 1. Aboveground fresh biomass, dry mass and total protein content of Jerusalem artichoke leaf protein concentrate (JAPC) isolated from green biomass of different clones

\section{JAPC yield}

218 Results of JAPC isolated from $1 \mathrm{~kg}$ fresh green biomass of Jerusalem artichoke clones by thermal coagulation are displayed in Table 1. Statistical analysis showed insignificant differences among

220 Jerusalem artichoke clones whether in $1^{\text {st }}$ or $2^{\text {nd }}$ harvests. The JAPC yield ranged from 28.3

221 (Fuseau) to 32.3 (Kalevala) $\mathrm{g} \mathrm{kg}^{-1}$ fresh biomass in the $1^{\text {st }}$ harvest, while in the $2^{\text {nd }}$ harvest JAPC

222 yield varied from 28 (Kalevala) to 30.4 (Alba) $\mathrm{g} \mathrm{kg}^{-1}$ fresh biomass (Table 1). However, results

223 showed that the average JAPC dry yield of the $1^{\text {st }}$ and $2^{\text {nd }}$ harvests were 30.8 and $29.1 \mathrm{~g} \mathrm{~kg}^{-1}$ fresh

224 biomass, respectively. Therefore, it could be calculated that $1 \mathrm{~kg}$ of green biomass of Jerusalem 225 artichoke gives approximately $30 \mathrm{~g}$ JAPC dry mass as an annual average.

\section{Total protein content of JAPC}


227

228

229

230

231

232

233

234

235

236

237

238

239

240

241

242

243

244

245

246

247

248

The total protein content $(\mathrm{m} / \mathrm{m} \%)$ of JAPC generated from fresh green biomass of Jerusalem artichoke clones ranged between $33.3 \mathrm{~m} / \mathrm{m} \%$ (Fuseau) and $35.3 \mathrm{~m} / \mathrm{m} \%$ (Alba) in the $1^{\text {st }}$ harvest, while in the $2^{\text {nd }}$ harvest it varied from $31.6 \mathrm{~m} / \mathrm{m} \%$ (Alba) to $35.2 \mathrm{~m} / \mathrm{m} \%$ (Fuseau). Statistically, no significant differences were calculated either between clones or between harvests (Table 1).

The average total protein content in the $1^{\text {st }}$ harvest was $34.1 \mathrm{~m} / \mathrm{m} \%$ and in the $2^{\text {nd }}$ harvest was $33.4 \mathrm{~m} / \mathrm{m} \%$. The annual average of total protein content of JAPC extracted from Jerusalem artichoke fresh biomass is estimated to be $33.8 \mathrm{~m} / \mathrm{m} \%$ (Table 1 ).

\section{Quantitative analysis of amino acid composition of JAPC}

The results of amino acid composition of JAPC obtained from green biomass of Jerusalem artichoke clones are presented in (Table 2). The essential amino acids (i.e., lysine, histidine, isoleucine, leucine, phenylalanine, methionine, threonine and valine) play a major role in feeding; therefore, they receive a special interest. Among the examined Jerusalem artichoke clones, Kalevala possessed the highest values of 5 out of the 8 essential amino acids (i.e., phenylalanine, histidine, isoleucine, threonine and valine). Also, aspartic acid, glycine, glutamic acid, proline and serine had the highest values 4.23, 2.13, 4.82, 2.20 and $1.90 \mathrm{~m} / \mathrm{m} \%$, respectively, in JAPC of Kalevala (Table 2). The concentration of lysine as essential amino acid has special importance in animal feeding. We found that the lysine content of Alba, Fuseau and Kalevala (ranged between 2.19 to $2.32 \mathrm{~m} / \mathrm{m} \%$, in the first harvest. The tendency of change in lysine content was similar but with higher values in the second harvest considering the Alba, Fuseau, Kalevala as their content varied from 2.35 to $2.54 \mathrm{~m} / \mathrm{m} \%$. The methionine is another limiting amino acid. The methionine content of Alba and Fuseau clones changed between 0.82 to $0.95 \mathrm{~m} / \mathrm{m} \%$ in both harvests (Table 2). Results, also, showed that lysine content increased in the $2^{\text {nd }}$ harvest compared to $1^{\text {st }}$ harvest 
for all clones; while, a reduction in methionine content was found in the $2^{\text {nd }}$ harvest compared to

$250 \quad 1^{\text {st }}$ harvest for all clones except Fuseau.

251

252

253

254

255

256

257

258

259

260
Table 2. Amino acid profile (\%) of Jerusalem artichoke leaf protein concentrate (JAPC) extracted from green biomass of different clones

\section{Quantitative analysis of fatty acid composition of JAPC}

Both saturated (SFA) and unsaturated fatty acids (UFA) could be detected from originated JAPC.

Polyunsaturated fatty acids (PUFA) including linoleic acid (C18:2 $\omega-6)$, linolenic acid (C18: $3 \omega$

$-3)$ and arachidonic acid $(\mathrm{C} 20: 4 \omega-6)$ were the predominant fatty acids $(66-68 \%)$ in all

Jerusalem artichoke clones (Figs 1 and 2). Among them linolenic acid (38.6-42.7\%) exhibits a

narrow range of distribution with highest values regardless of clones or harvesting time. The

Linoleic acid $(\mathrm{C} 18: 2 \omega-6)$ had the second highest concentration with $\min .23 .4 \%$ in $1^{\text {st }}$ harvest

JAPC of Kalevala and with max. $26.9 \%$ in $2^{\text {nd }}$ harvest JAPC of Alba. All analyzed JAPC had the lowest proportion of arachidonic acid $(\mathrm{C} 20: 4 \omega-6)$ at $0.3-0.6 \%$ of total fatty acids (Fig1).

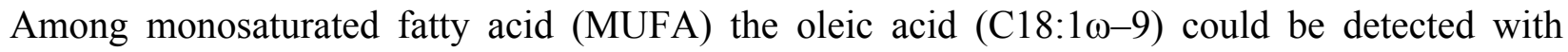
higher values $(6.6-11.6 \%)$. The proportion of palmioletic acid $(\mathrm{C} 16: 1 \omega-7)$ was significant lower, changed in the range of $0.7-1.1 \%$ (Fig 3). From saturated fatty acids (SFA) myristic acid (C14:0), palmitic acid (C16:0) and stearic acid (C18:0) could be separated. Palmitic acid (C16:0) was is the most abundant saturated component with no significant differences $(16.4-17.9 \%)$ considering the clones and harvesting time. The percentage composition of myristic acid (2.5 $6.9 \%)$ and stearic acid $(1.5-1.8 \%)$ in JAPC fractions were markedly lower compare to palmitic $\operatorname{acid}($ Fig 1). 
Fig 1. Fatty acid composition (\%) of Jerusalem artichoke leaf protein concentrate (JAPC) extracted from green biomass of different clones (Alba, Fuseau and Kalevala).

Fig 2. Distribution of saturated fatty acids (SFA), monounsaturated fatty acids (MUFA) and polyunsaturated fatty acids (PUFA) in Jerusalem artichoke leaf protein concentrate (JAPC) extracted from green biomass of different clones (Alba, Fuseau and Kalevala).

Reverse tendency of oleic acid and myristic acid content could be found considering the first and second harvest. Myristic acid content was higher in the $1^{\text {st }}$ harvest of JAPC of all three Jerusalem artichoke clones. While the oleic acid content was higher in the $2^{\text {nd }}$ harvest of JAPC of Alba and Kalevala clones (Fig1).

\section{Screening of phytochemicals of JAPC by UHPLC-ESI-MS}

The identification of compounds was primarily based on the correspondence of the ion from the deprotonated or protonated molecule using scientific literature results and fragmentation patterns of similar compounds. Profiles of phytochemicals of JAPCs isolated from different Jerusalem artichoke clones (i.e., Alba, Fuseau and Kalevala) showed negligible differences. Up to 61 phytochemicals were defined based on specific retention time, accurate mass, isotopic distribution and fragmentation pattern, and by screening MS databases like Metlin, mzCloud and Massbank (Table 3). Table 3 showed that the phenolic compounds were significant part of the identified compounds. Regardless of Jerusalem artichoke clones, all three caffeoyl quinic acid isomers could be identified in the JAPCs with a characteristic $[\mathrm{M}-\mathrm{H}]^{-}$ion at $\mathrm{m} / \mathrm{z} 353.0873$ measured by LC-ESI-MS technique in present experiment. In accordance with Yuan et al. [21] 3O-Caffeoylquinic acid was in highest ratio, while neochlorogenic and chryptochlorogenic acids were in fewer amounts (Fig 3). Along with it, we could identified three di-O-caffeoylquinic acid isomers exhibited $[\mathrm{M}-\mathrm{H}]^{-}$ion at $\mathrm{m} / \mathrm{z}$ 515.1190, four Coumaroylquinic acid isomers $[\mathrm{M}-\mathrm{H}]^{-}$ion 

alcoholic JAPC extracts. The measurement also revealed the existence of a compound with a $[\mathrm{M}-\mathrm{H}]^{-}$ion at $\mathrm{m} / \mathrm{z} 299.0767$ in all JAPC extracts. The ion scan experiment of this ion showed the corresponding fragment ions at $\mathrm{m} / \mathrm{z} 137.0233 ; 113.0229 ; 93.0331 ; 85.0281$ and 71.0122 . After comparison with database this compound was identified as salicylic acid-O-glucoside.

Table 3. Chemical composition of Jerusalem artichoke leaf protein concentrate (JAPC) extracted from green biomass

Fig 3. Extracted Ion Chromatograms (XIC) and MS spectra of selected phytoconstituents from Scopoletin; C: Loliolide; D: Liquiritigenin

Among flavonoids quercetin-O-glucoside with m/z 463.0877, isorhamnetin-3-O-glucoside with

$\mathrm{m} / \mathrm{z} 447.0927$ were found in all studied JAPC in agreement with Jerusalem artichoke related literature $[18,22]$. However, according to our knowledge this is the first time to identify

flavonols, most of the identified flavonoids are belonged to flavones. None of them have been 
and Fig 2). Liquiritigenin (4',7-Dihydroxyflavanone) $[\mathrm{M}-\mathrm{H}]^{-}$at $\mathrm{m} / \mathrm{z} 255.0657$ was the only

320 flavanone found in all studied JAPC of Jerusalem artichoke clones.

321 Besides polyphenols three different terpenes were consistently appeared in all studied JAPC of

322 Jerusalem artichoke clones. Loliolide as $\mathrm{C}_{11}$ monoterpenoid lactone was one of them exhibited

$323[\mathrm{M}+\mathrm{H}]^{+}$ion at $\mathrm{m} / \mathrm{z}$ 197.1178. As well as dihydroactinidiolide as a volatile monoterpene $[\mathrm{M}+\mathrm{H}]^{+}$

324 ion at m/z 181.1229 and 7-Deoxyloganic acid isomer as iridoid monoterpene $[\mathrm{M}-\mathrm{H}]^{-}$ion at $\mathrm{m} / \mathrm{z}$

325359.1342 were defined. Several proteinogen aminoacids (Table 3) could be identified. Among

326 vitamins we were able to identify some vitamin B such as nicotinic acid (niacin) $[\mathrm{M}+\mathrm{H}]^{+}$ion at

$327 \mathrm{~m} / \mathrm{z} 124.0399$ and riboflavin $[\mathrm{M}+\mathrm{H}]^{+}$ion at $\mathrm{m} / \mathrm{z}$ 377.1461. In addition, organic acids (i.e., malic

328 acid and citric acid) and plant hormones (i.e., indole acetic acid) could also be identified in

329 Jerusalem artichoke JAPC.

330 Fig 4. Extracted Ion Chromatoram of chlorogenic acid isomers

\section{Discussion}

333 Increasing the global demand for protein and with limited soy cultivation along with reliance on 334 many countries in imports; all make the search for alternatives a necessity. Hence, recently the interest in green biomass has been gained a wide attraction, as it may represent a relevant substitute of seed-based proteins. Jerusalem artichoke proved its ability to grow on a wide range

337 of soils with low inputs requirement. Moreover, it is tolerant to many biotic and abiotic stresses 338 such as insects, drought, heat and salinity [17]. For instance, in the harsh environments, it yields 339 around $30 \mathrm{Mg} \mathrm{ha}^{-1} \mathrm{DM}$ forage (aerial part) with $15.3 \%$ of crude protein [17]. These qualities 340 make Jerusalem artichoke a suitable candidate for a sustainable JAPC production with no 341 competition with the recognized fodder crops. Therefore, three Jerusalem artichoke clones 
342 representing three different climatic zones, such as humid continental (Hungary), arctic (Finland)

343 and hot desert climate (Egypt), were assessed for their JAPC production from a rain-fed

344 plantation with zero fertilizers.

345 Chloroplastic and cytoplasmic proteins of plant cells are the main source for JAPC production, 346 and they found at higher concentration in leaf tissues than in stem [23]. Young stems and leaves 347 of Jerusalem artichoke are succulent and turn to be woody with the time [15] therefore, in the 348 present study we harvested the aerial part two times during the growing season when reached 1.3

$349-1.5 \mathrm{~m}$ height, respectively. The fresh biomass aerial part of Jerusalem artichoke clones in 350 average was $5.3 \mathrm{~kg} \mathrm{~m}^{-2}$ in the first harvest and reduced to $2.4 \mathrm{~kg} \mathrm{~m}^{-2}$ in the $2^{\text {nd }}$ harvest. However, 351 the total measured fresh biomass of the aboveground part was $7.7 \mathrm{~kg} \mathrm{~m}^{-2}$; no significant 352 differences among studied clones were reported. Non-native varieties (Fuseau and Kalevala) 353 displayed high green biomass productivity under Hungarian climate. With average moisture 354 content of $47.8 \%$, it was calculated that total dry shoot biomass was $3.7 \mathrm{~kg} \mathrm{~m}^{-2}$ which is 355 equivalent to $36.8 \mathrm{Mg} \mathrm{ha}^{-1}$. This total dry biomass of aerial part was higher than this cited by 356 [23], who reported $25 \mathrm{Mg} \mathrm{ha}^{-1}$. It is important to be cognizant of the fact that this green biomass 357 was yielded from rain-fed plantation of Jerusalem artichoke; therefore, Jerusalem artichoke is 358 expected to produce higher aerial biomass yield since its shoot part is more sensitive to water 359 stress than tuber. According to [24] the irrigated plots of Jerusalem artichoke had higher 360 aboveground biomass by $98 \%$ than unirrigated plots.

361 Using aerial part of Jerusalem artichoke for animal feeding as fresh fodder or processed either in 362 the form of silage or feed formulations has long been known. However, this could be restricted 363 by trichomes which cover the surface of leaves and stem, as well as decreased protein and 364 increased lignin contents when plants become older [15,25]. Hence, processing extracts the 
protein from shoot part in the form of JAPC is vital for increasing the economic value of

Jerusalem artichoke. Another reason for the importance of JAPC production is that fresh stem is average, $10.2 \%$ fresh mass of JAPC. These results emphasize that Jerusalem artichoke has the qualities of what makes it suitable candidate for JAPC production.

371 Average total protein content of JAPC generated from Alba, Fuseau and Kalevala clones was

$37233.4 \mathrm{~m} / \mathrm{m} \%$. However, most of isolated protein is referred to leaves as Jerusalem artichoke leaves

373 contain three times higher total protein than stem [27]; our results were in agreement with these

374 findings. Total protein content of JAPC extracted mainly from leaves most of which is made up

375 of assimilation parenchyma tissue (80-87\%) with easily released cytoplasmic and chloroplast

376 proteins. Rubisco has the greatest significance among leaf soluble protein with its high nutritional

377 value [28]. Harvesting time of aerial part is critical from the aspects of quantity and quality of

378 JAPC production. Rashchenko [29] reported that nitrogen content in older leaves decreased by

379 approximately $50 \%$ compared to young leaves. Seiler [30], also, reported that total protein

380 reduced by $32.6 \%$ from vegetative to flowering stage of Jerusalem artichoke plants. Knowing

381 this, the shoots were harvested in the maximum green leaf state $(1.3-1.5 \mathrm{~m})$ ahead of senescence

382 and avoiding the dryness of bottom leaves. Following this thread, the results showed no big

383 difference in protein content between the two harvests.

384 When it comes to the ideal protein source, the amino acid profile cannot be ignored because 385 among the 20 proteinogenic amino acids nine cannot be synthetized by most animal species [31].

386 The ratio of these essential amino acids has special interest. Among green biomass originated 387 fractions, JAPC as dedicated protein enriched product for feed was examined more thoroughly. 
Several indispensable amino acids i.e., lysine, isoleucine, leucine, methionine and threonine showed high content in JAPC. However, higher contents of amino acids in JAPC were reported by [23]; this could be attributed to the different extraction method and different varieties. The results of amino acids exhibited minor measured differences between the two harvests; this could be due to the different weather and plant age as has been previously documented $[15,29,30]$.

Several literatures discussed the fatty acid and lipid content in tubers of Jerusalem artichoke [15,32]; however, meager information about fatty acid composition in leaves is available in scientific studies. Nowadays, there is a growing attention in polyunsaturated fatty acids (PUFA) because humans and other mammals are incapable to synthesize omega- 6 and omega-3 PUFA in the lack of delta $(\Delta) 12$ and $\Delta 15$ desaturase enzymes. These enzymes are responsible to insert cis double bond at the n-6 or n-3 positions [5]. Hence, linolenic acid (C18: $3 \omega-3)$ and linoleic acid

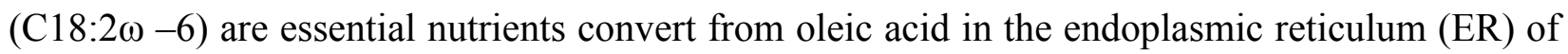
plant cells. Linolenic acid is the precursor of longer-chain PUFA such as eicosapentaenoic acid

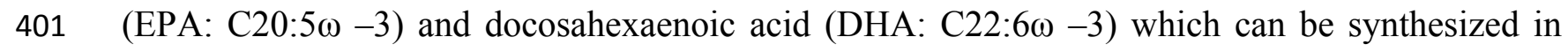
human. Similarly linoleic acid $(\mathrm{C} 18: 2 \omega-6)$ is also essential precursor to synthesize dihomo- $\gamma$ -

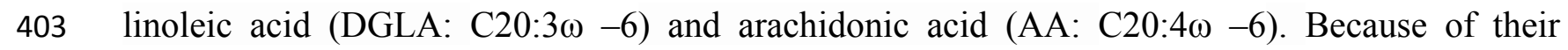
essentiality, linolenic acid and linoleic acid need to be supplied with a diet of animals or humans.

405 Regardless of observed clones the highest contribution to the fatty acid profile were noted for 406 linolenic acid (C18: $3 \omega-3)$ with $38.6-42.7 \%$ values and linoleic acid (C18:2 $\omega-6)$ with $23.4-$ $26.9 \%$ in JAPCs (Fig 1). Along with anthropological and epidemiological studies right 408 proportion of linoleic acid and linolenic acid should be emphasized. The ratio of omega-6 to 409 omega-3 essential fatty acids evolved $\sim 1: 1$ in the evolutionary history of human diet In contrast, 410 following the current Western diet the ratio has shifted to 10-20:1 which is not desirable from 
411 health aspect and promotes the pathogenesis of many diseases [33]. We found $\sim 0.6: 1$ ratio of 412 omega-6 to omega-3 essential fatty acids in JAPC which is very favorable, close to the 413 Paleolithic nutrition.

414 Arachidonic acid as a PUFA could also be measured from JAPC even at low proportion $(0.3-$ $4150.6 \%$ ) in agreement with Shanab et al. [34] who found little amounts of AA are in terrestrial 416 plants. Arachidonic acid mainly could be identified in many algal groups, which grow 417 photoautotrophically or heterotrophically. Among marine macroalgae AA can reach $60 \%$ of total 418 FAs content in case of Gracilaria sp. red alga.

419 The saturated palmitic acid (C16:0), stearic acid (C18:0) and the monosaturated form of stearic

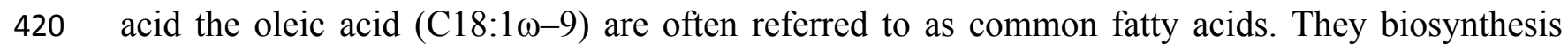
421 occurs in plastids and partially incorporated into cell and subcellular membranes [35]. The JAPC 422 originated mainly from crushed cells of vegetative tissues containing membrane debris. This 423 explains the relative higher proportion of palmitic acid (16.4 - 17.9\%) and oleic acid (6.6 $42411.6 \%$ ). Considering the harvesting time, oleic acid content of Alba and Kalevala JAPC showed 425 higher value in the $2^{\text {nd }}$ harvest (when the nights were colder). According to Barrero-Sicilia et al.

426 [36] plants often respond to low temperature by increasing unsaturated fatty acids in membrane 427 along with increased membrane fluidity and stabilization. We found reverse tendency in saturated 428 myristic acid (C14:0) content of JAPC. It showed higher values in the $1^{\text {st }}$ harvest (when the nights were warmer) in case of all three Jerusalem artichoke clones.

430 The phytochemical screening by UHPLC ESI MS was performed in both negative and positive 431 ESI modes owing to the varying ionization requirements of compounds. Negative mode was used 432 for identification of flavonoid and phenolic acid (hydroxycinnamic acid and benzoic acid) 433 derivatives which provided better sensitivity. The easy protonation of nitrogen in positive mode 
434 made it suitable for identification of terpenes, amino acids and coumarins, coumarylquinic acids.

435 Within non-flavonoid phenolic constituents, the caffeoyl quinic acid as also called chlorogenic

436 acid isomers are important subgroup and their presence is characteristic of Asteraceae family.

437 According to some literature the chlorogenic acid (3-O-Caffeoylquinic acid) is the most abundant

438 isomer in plant sources, while the cryptochlorogenic acid (4-O-Caffeoylquinic acid) and

439 neochlorogenic acid (5-O-Caffeoylquinic acid) are in low concentrations [37]. Yuan et al. [21]

440 found 3-O-Caffeoylquinic acid and 1,5-dicaffeoyl quinic acid in the highest concentration in

441 Jerusalem artichoke extracted leaves. However, Liang and Kitts [38] reported that generally the

442 5-O-Caffeoylquinic acid is the predominant isomer in fruits and vegetables. The presence of

443 these phenolic acids is interesting from both human and animal aspects because of several

444 biological roles are attributed to caffeoyl quinic acid isomers in such as antioxidant activity,

445 antibacterial, hepatoprotective, cardioprotective, anti-inflammatory, antipyretic, neuroprotective,

446 anti-obesity, antiviral, anti-hypertension, and a central nervous system stimulator. In addition,

447 they can be confirmed to modulate lipid metabolism and glucose in both genetically and healthy

448 metabolic related disorders [21,39]. Based on the health promoting effects, caffeoyl quinic acid

449 isomers are increasingly recommended as natural and safe food additive supplement instead of 450 synthetic antibiotics and immune boosters.

451 The presence of coumarins as non-flavonoid polyphenols has also been revealed from JAPC

452 fractions of Jerusalem artichoke. Scopoletin, isoscopoletin, were identified with a characteristic

$453[\mathrm{M}+\mathrm{H}]^{+}$ion at $\mathrm{m} / \mathrm{z}$ 193,05, in addition 6-methylcoumarin and fraxidin were also found in 454 assessable quantities.

455 Flavonoids are widespread secondary metabolites within phenolic constituents in plant kingdom.

456 However, few of them were described in Jerusalem artichoke such as isorhamnetin glucoside, 
457 kaempferol glucuronide and kaempferol-3-o-glucoside from leaves [18]. In present study, 18

458 flavonoids were recognized in JAPC (Table 3). Generally, cell vacuoles are the main storage of

459 soluble flavonoids. Primarily, the solubility of flavonoids is due to the different sugar

460 substitution. Because of JAPC is coagulated pressed green juice - which mainly contain the

461 cytoplasm included vacuoles - this could be one of the reasons of the relatively more flavonoids

462 found in the present study. Among sugars glucose and glucuronic acid at a single position is

463 probably the most common substituents [40]. In screened JAPC, glycosylated flavonoids were

464 occurred. The importance of flavonoid glucuronides is related to health-promoting activities such

465 as anti-inflammatory and neuroprotective activities of quercetin-3- $O$-glucuronide [41].

466 Most of identified flavonoid compounds by UHPLC-ESI-MS technique belonged to the flavones.

467 All of identified flavones were hydroxylated methoxyflavone which mean one or more methoxy

468 groups on flavone basic framework besides/instead of hydroxyl groups. Substitution of a

469 methoxy group for the hydroxyl group in flavones has significant importance. One side the

470 hydroxyl groups flavones have free radical scavenging activity, but extensive conjugation of free

471 hydroxyl groups to flavones results in low oral bioavailability hence they undergo rapid sulfation

472 and glucuronidation in the small intestine and liver by phase II enzymes; consequently,

473 conjugated metabolites can be found in plasma not the original compounds [42]. However, if one

474 or more hydroxyl groups are capped by methylation, the substitution of a methoxy group by the

475 hydroxyl group induces an increase in metabolic stability, improves transport and absorption.

476 Considering the biological properties and chemical characteristics of hydroxyl and methoxy

477 groups together, the hyroxylated methoxyflavones combine many advantages of both functional

478 groups, improving their potential for application in human health [42]. Therefore, the several

479 hyroxylated methoxyflavones such as dimethoxy-trihydroxyflavone isomers; dimethoxy-

480 tetrahydroxyflavone; dihydroxy-methoxyflavone, trihydroxy-trimethoxyflavone, hymenoxin and 
nevadensin increase the value of JAPC. liquiritigenin (4',7-Dihydroxyflavanone) which has been previously identified by Johansson et al. [17] in flower of Helianthus tuberosus was found in our JAPC. The liquiritigenin is known as promising active estrogenic compound, it is highly selective

484 estrogen receptor $\beta$ agonist. It might be helpful to women who suffer from the menopause symptoms [43].

486 Three different terpenes were consistently appeared in all tested JAPCs of Jerusalem artichoke 487 clones. Loliolide as $\mathrm{C}_{11}$ monoterpenoid lactone is considered as a photo-oxidative or thermal 488 degraded product of carotenoids [44]. Similarly, we could identify dihydroactinidiolide as a 489 volatile monoterpenoid. It is a flavor component in several plants, such as tobacco and tea. 490 According to Yun et al. [45] thermal treatment induce the formation of dihydroactinidiolide from $491 \beta$-carotene. Kaszás et al. [11] confirmed that the green juice contains markedly amount of 492 carotenoids which probably can partially convert to loliolide or dihydroactinidiolide as reason of 493 detected terpenes. Role of loliolide is confirmed by some scientific studies. According to these 494 studies, growth and germination inhibition, as well as phytotoxic activities were demonstrated in 495 plants, in addition to repellent effect against ants and antitumor, antimicrobial activities for 496 animals and microorganisms [44,46]. Dihydroactinidiolide has carbonyl group that can react with 497 nucleophilic structures in macromolecules, providing high potential reactivity to the molecules. It 498 is also showed cytotoxic effects against cancer cell lines Yun et al. [45]. The 7-Deoxyloganic 499 acid isomer was the other terpene, which is known, as intermediate in secoiridoid pathway in 500 plants.

501 In summary, the current study delivered deeper insights into JAPC evaluation originating from 502 fractionated green biomass of different Jerusalem artichoke clones. However future studies on 
503 anti-nutritional ingredients of JAPC as well as chemical composition of other fractions such as

504 brown juice and fiber along with economically calculation are needed to be address.

\section{Conclusion}

506 Considering the high amount of lingo-cellulose shoot biomass and inulin enriched tubers several

507 literatures suggest the utilization of Jerusalem artichoke in biorefinery context. Less information

508 is available about the green biomass utilization for green biorefinery purposes even Jerusalem

509 artichoke has repeatedly harvestable leafy shoot with valuable biochemical compounds. At least

510 one value-added product is necessary to produce in order to achieve cost-effective green bio-

511 refinery. Hence in the present research paper, we tried to highlight and deliver more information

512 about leaf protein concentrate (JAPC) generated from different Jerusalem artichoke clones using

513 biotechnological method. It can be harvested two times a year generating valuable quantities of

514 green aerial biomass under low inputs condition. Yield of JAPC was almost the same among

515 studied Jerusalem artichoke clones. Amino acids and fatty acid compositions, as value indicator

516 parameters, were similar in JAPC generated from Jerusalem artichoke clones. Present

517 biochemical analysis revealed that the JAPC is not only a good source of protein with favorable

518 amino acid composition but also it is repository of essential fatty acids, flavonoid and non-

519 flavonoid phytonutrients. We found that the quantity and/or quality of phytochemicals are

520 specific primarily for the Jerusalem artichoke species and for the technological way. Within the

521 species, slight difference can be revealed in the examined parameters between the clones. Results

522 of present work confirm that this underestimated plant can be directed not only towards tuber

523 production for inulin extraction, but the green biomass can also represent a value for JAPC

524 production under low inputs in green biorefineries. 


\section{Acknowledgment}

526 The authors thank Prof. Mohamed E. Ragab (Horticulture Department, Faculty of Agriculture,

527 Ain Shams University, Egypt) for providing them with tubers of Fuseau.

\section{References}

529 1- Henchion M, Hayes M, Mullen AM, Fenelon M, Tiwari B. Future protein supply and demand:

530 strategies and factors influencing a sustainable equilibrium. Foods. 2017; 6(7):53.

531 2- Pojić M, Mišan A, Tiwari B. Eco-innovative technologies for extraction of proteins for human 532 consumption from renewable protein sources of plant origin. Trends in Food Science \& $533 \quad$ Technology. 2018; 75:93-104.

534 3- Chardigny J-M, Walrand S. Plant protein for food: opportunities and bottlenecks. OCL. 2016; 23(4) D404.

5- Grela ER, Pietrzak K. Production technology, chemical composition and use of alfalfa protein xanthophyll concentrate as dietary supplement. Journal of Food Processing \& Technology. 2014; 5:10. DOI:10.4172/2157-7110.1000373 2016; 197:1341-1345. 
544

545

546

547

548

549

550

551

552

553

554

555

556

557

558

559

560

561

562

563

564

7- Solati Z, Jørgensen U, Eriksen J, Søegaard K. Dry matter yield, chemical composition and estimated extractable protein of legume and grass species during the spring growth. J. Sci. Food Agric. 2017; 97(12):3958-3966.

8- Tamayo-Tenorio A, Schreuders FKG, Zisopoulos FK, Boom RM, van der Goot AJ. Processing concepts for the use of green leaves as raw materials for the food industry. Journal of Cleaner Production. 2017; 64:736-748.

9- Santamaría-Fernández M, Molinuevo-Salces B, Kiel P, Steenfeldt S, Uellendahl H, Lübeck M. Lactic acid fermentation for refining proteins from green crops and obtaining a high quality feed product for monogastric animals. Journal of Cleaner Production. 2017; $162: 875-881$

10- Fang YR, Liua JA, Steinberger Y, Xie GH. Energy use efficiency and economic feasibility of Jerusalem artichoke production on arid and coastal saline lands Industrial Crops \& Products. 2018; 117:131-139.

11- Kaszás L, Kovács Z, Nagy É, Elhawat N, Abdalla N, Domokos-Szabolcsy É. Jerusalem artichoke (Helianthus Tuberosus L.) as a potential chlorophyll source for humans and animals nutrition. Environmental, Biodiversity and Soil Security. 2018; 2:1-9.

12- Gunnarsson IB, Svensson S-E, Johansson E, Karakashev D, Angelidaki I. Potential of Jerusalem artichoke (Helianthus tuberosus L.) as abiorefinery crop. Industrial Crops and Products. 2014; 56:231-240.

13- Razmkhah M, Rezaei J, Fazaeli H. Use of Jerusalem artichoke tops silage to replace corn silage in sheep diet. Animal Feed Science and Technology. 2017; 228:168-177. 

and Jerusalem artichoke biomass under nitrogen applications in coastal saline zone in the northern region of Jiangsu. China. Sci Total Environ. 2016; 568:885-890.

15- Kays SJ, Nottingham SF. Biology and chemistry of Jerusalem artichoke: Helianthus tuberosus L. CRC Press, Taylor \& Francis Group, New York, USA. 2008.

16- Long XH, Shao HB, Liu L, Liu LP, Liu ZP. Jerusalem artichoke: A sustainable biomass feed stock for biorefinery. Renewable and Sustainable Energy Reviews. 2016; 54:1382-1388. Economically viable components from Jerusalem artichoke (Helianthus tuberosus L.) in a (Helianthus tuberosus L.) responding to salt-stress by Liquid Chromatography/Tandem Mass Spectrometry. The Scientific World J. 2014; 568043.

19- Sparks DL, Page AL, Helmke PA, Loppert RH, Soltanpour PN, Tabatabai MA, et al.

20- Duncan DB. Multiple range and multiple F-tests. Biometric 1955; 11:1-42.

581 21- Yuan X, Gao M, Xiao H, Tan C, Du Y. Free radical scavenging activities and bioactive substances of Jerusalem artichoke (Helianthus tuberosus L.) leaves. Food Chemistry. $2012 ; 133: 10-14$. tuberosus. Natural Product Sci. 2002; 8(4):141-143. 
23- Rawate PD, Hill RM. Extraction of a high-protein isolate from Jerusalem artichoke (Helianthus tuberosus) tops and evaluation of its nutrition potential. J. Agric. Food Chem. $1985 ; 33: 29-31$

24- Mecella G, Scandella P, Neri U, Di Blasi N, Moretti R, Troisi A, et al. The productive and chemical evolution of the Jerusalem artichoke (Helianthus tuberosus L.) under various conditions of irrigation. Agric. Med. 1996; 126:233-239. the culture and certain varieties of the Jerusalem artichoke, USDA Technical Bulletin 415, U.S. Department of Agriculture, Washington, DC. 1936. regions: a preliminary study of the yield and nutritional quality of shoot tissues from perennial stands. J. Sci. Food Agric. 1992; 60:213-221.

27- Malmberg A, Theander O. Differences in chemical composition of leaves and stem in Jerusalem artichoke and changes in low-molecular sugar and fructan content with time of harvest. Swed. J. Agric. Res. 1986; 16:7-12.

28- Lamsal BP, Koegel RG, Gunasekaran S. Some physicochemical and functional properties of alfalfa soluble leaf proteins. LWT. 2007; 40:1520-1526. Kazakh. Sel'skokhoz. Inst. 1959; 6:40-52. Jerusalem artichoke, Agron. J. 1988; 80:681-687. 
607

608

609

610

611

612

613

614

615

31- Boisen S, Hvelplund T, Weisbjerg MR. Ideal amino acid profiles as a basis for feed protein evaluation. Livestock Production Sci. 2000; 64:239-251.

32- Chernenko TV, Glushenkova AI, Rakhimov DA. Lipids of Helianthus tuberosus tubers. Chemistry of Natural Compounds. 2008; 44(1):1-2.

33- Simopoulos AP. Evolutionary aspects of diet, the omega-6/omega-3 ratioand genetic variation: nutritional implications for chronic diseases Biomedicine \& Pharmacotherapy. 2006; 60:502-507.

34- Shanab SMM, Hafez RM, Fouad AS. A review on algae and plants as potential source of arachidonic acid J. Adv. Res. 2018; 11:3-13.

35- Sadali NM, Sowden RG, Ling Q, Jarvis RP. Differentiation of chromoplasts and other plastids in plants. Plant Cell Reports. 2019; 38:803-818.

36- Barrero-Sicilia C, Silvestre S, Haslam RP, Michaelson LV. Lipid remodelling: Unravelling the response to cold stress in Arabidopsis and its extremophile relative Eutrema salsugineum. Plant Sci. 2017; 263:194-200.

37- Naveed M, Hejazi V, Abbas M, Kamboh AA, Khan GJ, Shumzaid M, et al. Chlorogenic acid (CGA): A pharmacological review and call for further research. Biomed Pharmacother. 2018; 97:67-74.

38- Liang N, Kitts DD. Role of chlorogenic acids in controlling oxidative and inflammatory stress conditions. Nutrients. 2015; 8(1):16. doi:10.3390/nu8010016

39- Zhang L, Chang C, Liu Y, Chen Z. Effect of chlorogenic acid on disordered glucose and lipid metabolism in db/db mice and its mechanism. Acta Academiae Medicinae Sinicae 2011; 33(3):281-286. 
40- Docampo M, Olubu A, Wang X, Pasinetti G, Dixon RA. Glucuronidated flavonoids in neurological protection: structural analysis and approaches for chemical and biological synthesis. Journal of agricultural and food chemistry. 2017; 65(35):7607-7623.

41- Ho L, Ferruzzi MG, Janle EM, Wang J, Gong B, Chen T-Y, et al. Identification of braintargeted bioactive dietary quercetin-3-O-glucuronide as a novel intervention for Alzheimer's disease. FASEB J. 2013; 27:769-781.

42- Lai CS, Wu JC, Ho CT, Pan MH. Disease chemopreventive effects and molecular mechanisms of hydroxylated polymethoxyflavones. BioFactors. 2015; 41(5):301-313.

43- Mersereau JE, Levy N, Staub RE, Baggett S, Zogovic T, Chow S, et al. Liquiritigenin is a plant-derived highly selective estrogen receptor beta agonist. Mol Cell Endocrinol. 2008; 283(1-2):49-57.

44- Murata M, Nakai Y, Kawazu K, Ishizaka M, Kajiwara H, Abe H, et al. Loliolide, a carotenoid metabolite, is a potential endogenous inducer of herbivore resistance. Plant Physiol. 2019; 179(4):1822-1833.

45- Yun N, Kang JW, Lee SM. Protective effects of chlorogenic acid against ischemia/reperfusion injury in rat liver: molecular evidence of its antioxidant and antiinflammatory properties. J. Nutr. Biochem. 2012; 23(10):1249-1255.

46- Islam MS, Iwasaki A, Suenaga K, Kato-Noguchi H. 2017. Isolation and identification of two potential phytotoxic substances from the aquatic fern Marsilea crenata. J Plant Biol. 2017; 60:75-81. 


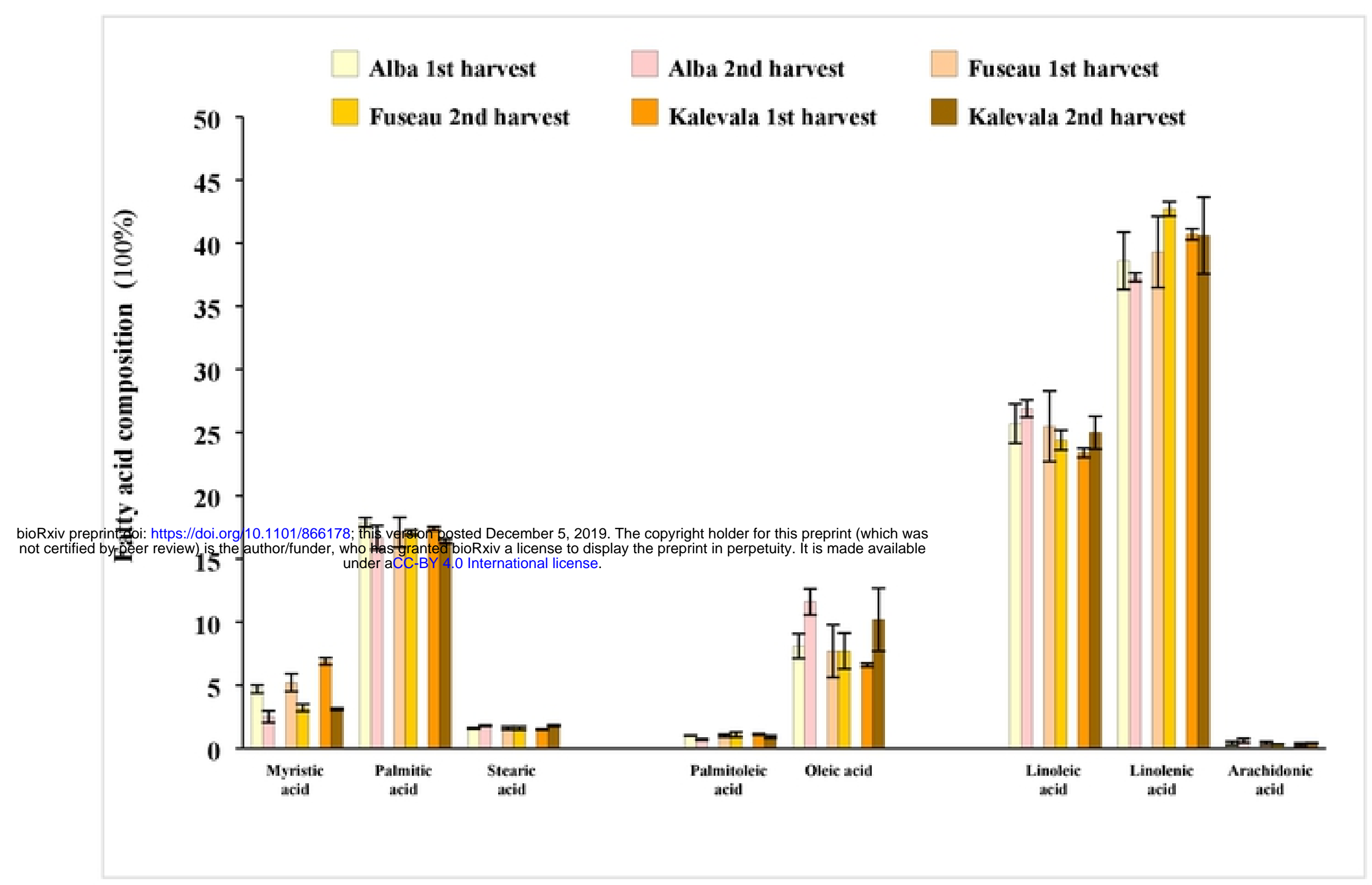

Fig 1. Fatty acid profile (100\%) of Jerusalem artichoke leaf protein concentrate (JAPC) extracted from green biomass of different clones (Alba, Fuseau and Kalevala).

Figure 1 


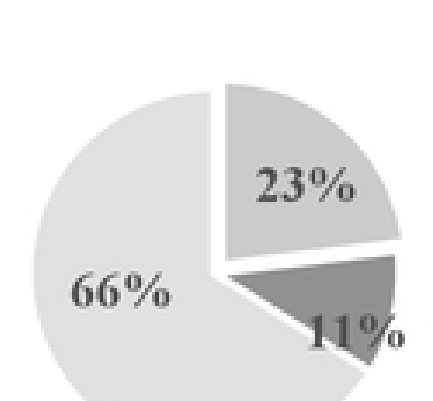

Chart Title

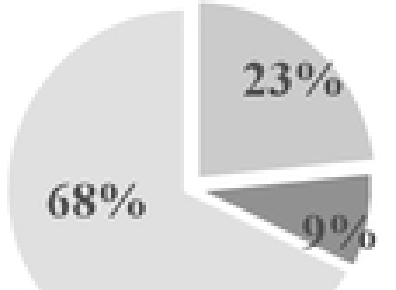

Fuseau

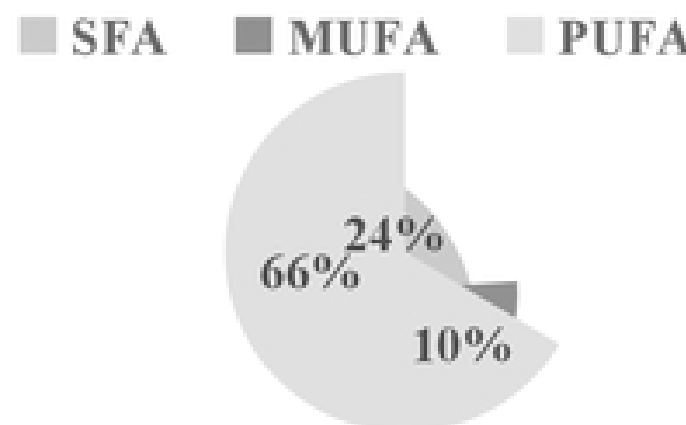

Kalevala

Fig 2. Distribution of saturated fatty acids (SFA), monounsaturated fatty acids (MUFA) and polyunsaturated fatty acids (PUFA) in Jerusalem artichoke leaf protein concentrate (JAPC) extracted from green biomass of different clones (Alba, Fuseau and Kalevala).

bioRxiv preprint doi: https://doi.org/10.1101/866178; this version posted December 5, 2019. The copyright holder for this preprint (which was not certified by peer review) is the author/funder, who has granted bioRxiv a license to display the preprint in perpetuity. It is made available 


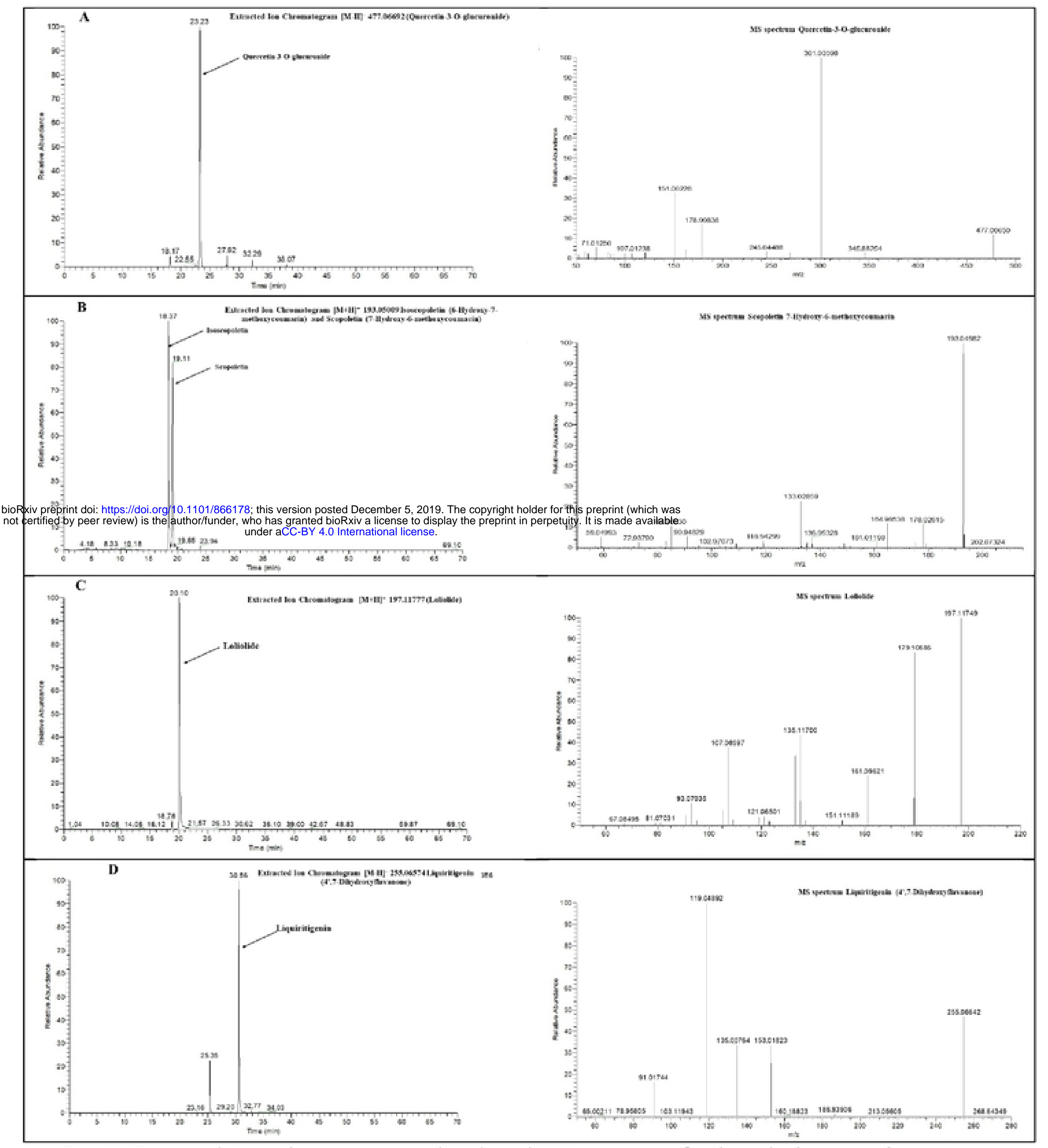

Fig 3. Extracted Ion Chromatograms (XIC) and MS spectra of selected phytoconstituents from Jerusalem artichoke leaf protein concentrate: A: quercetin- 3-O-glucuronide; B: Scopoletin; C: Loliolide; D: Liquiritigenin 


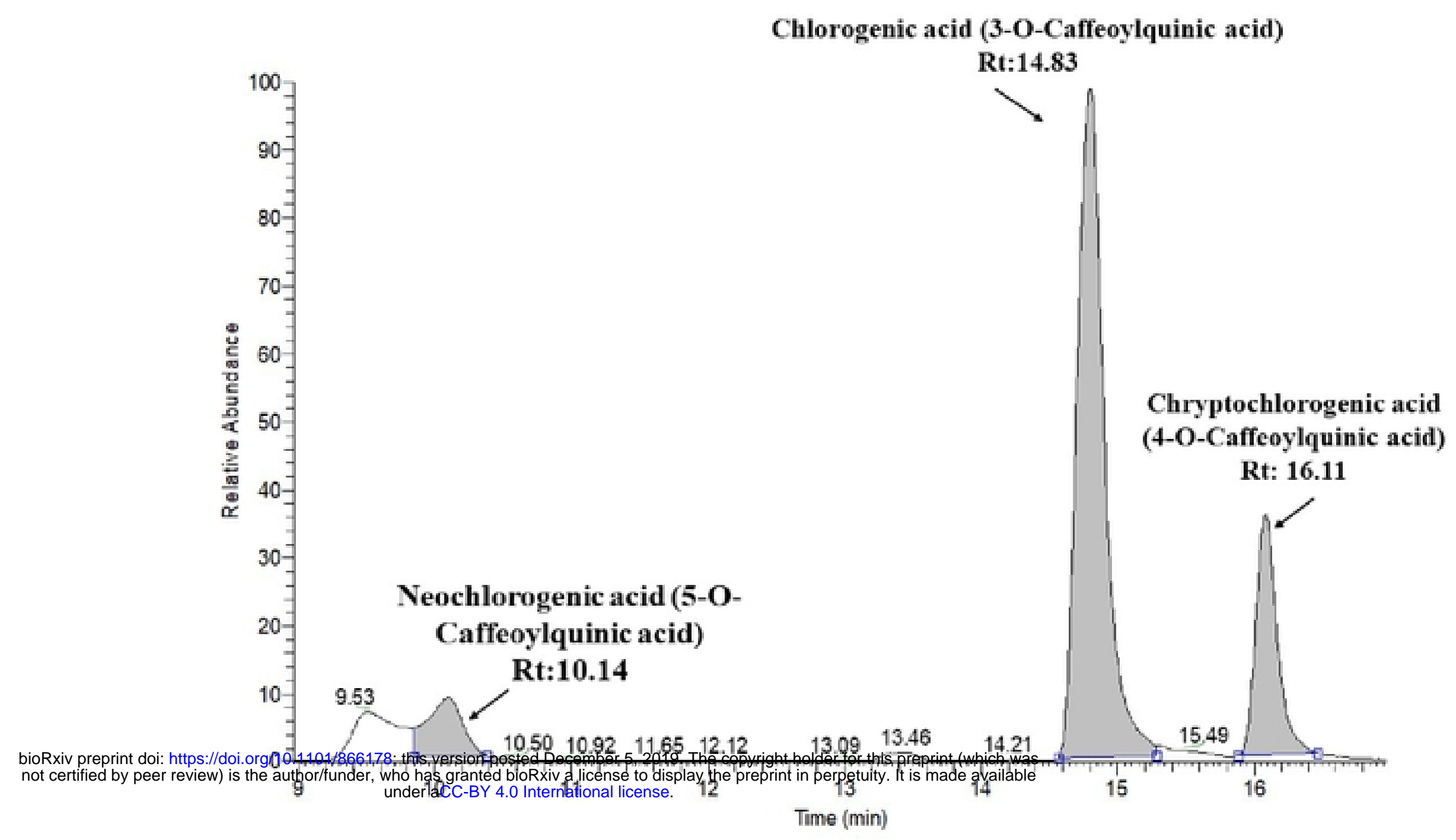

Fig 4. Extracted Ion Chromatoram of chlorogenic acid isomers 
Table 1. Aboveground fresh biomass, dry mass and total protein content of Jerusalem artichoke leaf protein concentrate (JAPC) isolated from green biomass of different clones

\begin{tabular}{lcccccc}
\hline \multirow{2}{*}{ Clones } & \multicolumn{2}{c}{ Fresh Biomass yield $\left(\mathrm{kg} \mathrm{m}^{-2}\right)$} & \multicolumn{2}{c}{ JAPC $\left(\mathrm{g} \mathrm{kg}^{-1}\right.$ fresh biomass) dry basis } & \multicolumn{2}{c}{ Total Protein \% } \\
\cline { 2 - 7 } & $1^{\text {st }}$ harvest & $2^{\text {nd }}$ harvest & $1^{\text {st }}$ harvest & $2^{\text {nd }}$ harvest & $1^{\text {st }}$ harvest & $2^{\text {nd }}$ harvest \\
Alba & $5.0 \pm 0.43 \mathrm{a}$ & $1.8 \pm 0.22 \mathrm{~b}$ & $31.9 \pm 2.7 \mathrm{a}$ & $30.4 \pm 3.2 \mathrm{a}$ & $35.3 \pm 0.8 \mathrm{a}$ & $31.6 \pm 0.8 \mathrm{~b}$ \\
Fuseau & $5.2 \pm 0.28 \mathrm{a}$ & $2.6 \pm 0.19 \mathrm{ab}$ & $28.3 \pm 1.9 \mathrm{a}$ & $28.8 \pm 2.8 \mathrm{a}$ & $33.3 \pm 0.9 \mathrm{a}$ & $35.2 \pm 0.8 \mathrm{a}$ \\
Kalevala & $5.6 \pm 0.65 \mathrm{a}$ & $2.8 \pm 0.57 \mathrm{a}$ & $32.3 \pm 2.1 \mathrm{a}$ & $28.0 \pm 2.7 \mathrm{a}$ & $33.8 \pm 0.7 \mathrm{a}$ & $33.4 \pm 0.7 \mathrm{ab}$ \\
\hline
\end{tabular}

Means followed by different letters in the same column show significant differences according to Duncan's test at $\mathrm{p}<$ 0.05 .

bioRxiv preprint doi: https://doi.org/10.1101/866178; this version posted December 5, 2019. The copyright holder for this preprint (which was 
Table 2. Amino acid profile $(\mathrm{m} / \mathrm{m} \%)$ of Jerusalem artichoke leaf protein concentrate (JAPC) extracted from green biomass of different clones

\begin{tabular}{|c|c|c|c|c|c|c|}
\hline & \multicolumn{2}{|c|}{ Alba } & \multicolumn{2}{|c|}{ Fuseau } & \multicolumn{2}{|c|}{ Kalevala } \\
\hline & $1^{\text {st }}$ harvest & $2^{\text {nd }}$ harvest & $1^{\text {st }}$ harvest & $2^{\text {nd }}$ harvest & $1^{\text {st }}$ harvest & $2^{\text {nd }}$ harvest \\
\hline Lysine & 2.32 & 2.35 & 2.19 & 2.54 & 2.25 & 2.46 \\
\hline Histidine & 0.80 & 0.72 & 0.71 & 0.76 & 0.83 & 0.82 \\
\hline Isoleucine & 1.72 & 1.72 & 1.64 & 1.86 & 1.77 & 1.78 \\
\hline Leucine & 3.25 & 3.19 & 3.08 & 2.46 & 3.31 & 3.30 \\
\hline Phenylalanine & 2.12 & 2.03 & 1.96 & 2.20 & 2.19 & 2.18 \\
\hline Methionine & 0.87 & 0.82 & 0.84 & 0.95 & 0.79 & 0.77 \\
\hline Threonine & 1.96 & 1.95 & 1.87 & 2.12 & 2.33 & 2.33 \\
\hline Valine & 2.05 & 2.10 & 2.02 & 2.34 & 2.06 & 2.09 \\
\hline Alanine & 2.36 & 2.32 & 2.20 & 2.47 & 2.35 & 2.34 \\
\hline 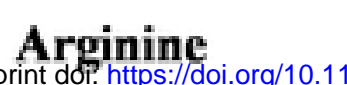 & $\begin{array}{l}2208 \\
178 \text { : this vers }\end{array}$ & mber $_{5.201}^{1.87}$ & $\begin{array}{l}1,88 \\
\text { holder fort }\end{array}$ & $\begin{array}{c}1,97 \\
\text { ch was }\end{array}$ & 1.86 & 2.21 \\
\hline $\begin{array}{l}\text { by peer reviewe is ithe auth a } \\
\text { Aspartic acid }\end{array}$ & 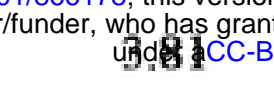 & 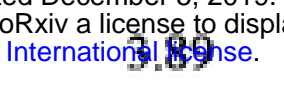 & $\begin{array}{l}\text { tinperpetuit } \\
\text { tin }^{2}\end{array}$ & ailable 4.23 & 4.23 & 4.24 \\
\hline Cysteine & 0.24 & 0.24 & 0.22 & 0.26 & 0.22 & 0.23 \\
\hline Glycine & 2.04 & 1.99 & 1.93 & 2.14 & 2.13 & 2.14 \\
\hline Glutamic acid & 4.29 & 4.38 & 4.14 & 4.74 & 4.82 & 4.79 \\
\hline Proline & 1.92 & 2.04 & 1.82 & 2.18 & 2.20 & 2.19 \\
\hline Serine & 1.74 & 1.77 & 1.67 & 1.89 & 1.90 & 1.93 \\
\hline Tyrosine & 1.48 & 1.42 & 1.38 & 1.61 & 1.46 & 1.55 \\
\hline Ammonia & 0.49 & 0.52 & 0.47 & 0.48 & 0.52 & 0.54 \\
\hline
\end{tabular}


Table 3. Chemical composition of Jerusalem artichoke leaf protein concentrate (JAPC) extracted from green biomass

\begin{tabular}{|c|c|c|c|c|c|c|c|c|c|c|}
\hline No. & Compound & Formula & $\begin{array}{l}\text { Retention } \\
\text { time }\end{array}$ & {$[\mathrm{M}+\mathrm{H}]^{*}$} & {$[\mathrm{M}-\mathrm{H}]^{-}$} & $\begin{array}{l}\text { Fragmens } \\
\quad 1\end{array}$ & $\begin{array}{l}\text { Fragmens } \\
2\end{array}$ & $\begin{array}{l}\text { Fragmens } \\
3\end{array}$ & $\begin{array}{l}\text { Fragmens } \\
4\end{array}$ & $\begin{array}{c}\text { Fragmens } \\
5\end{array}$ \\
\hline 1 & Lysine & $\mathrm{C} 6 \mathrm{H} 14 \mathrm{~N} 2 \mathrm{O} 2$ & 1,12 & 147,11336 & & 130,0866 & 84,0814 & 67,0547 & 56,0503 & \\
\hline 2 & $\gamma$-Aminobutyric acid & C4H9NO2 & 1,25 & 104,07116 & & 87,0446 & 86,0607 & 69,0342 & 58,0658 & \\
\hline 3 & Quinic acid & C7H12O6 & 1,27 & & 191,05557 & 173,0447 & 171,0289 & 127,0388 & 93,0331 & 85,0280 \\
\hline 4 & Betaine (Trimethylglycine) & C5H11NO2 & 1,28 & 118,08681 & & 59,0737 & 58,0659 & & & \\
\hline 5 & Proline & C5H9NO2 & 1,28 & 116,07116 & & 70,0658 & 68,0500 & & & \\
\hline 6 & Glutamic acid & C5H9NO4 & 1,32 & 148,06099 & & 130,0502 & 102,0555 & 84,0450 & 56,0502 & \\
\hline 7 & Glutamine & C5H1ON2O3 & 1,32 & 147,07697 & & 130,0502 & 102,0554 & 101,0716 & 84,0450 & 56,0502 \\
\hline 8 & Malic acid & $\mathrm{C} 4 \mathrm{H} 6 \mathrm{O} 5$ & 1,33 & & 133,01370 & 115,0024 & 89,0230 & 87,0075 & 72,9916 & 71,0123 \\
\hline 9 & Nicotinic acid (Niacin) & C6H5NO2 & 1,51 & 124,03986 & & 96,0450 & 80,0501 & 78,0347 & & \\
\hline 10 & Citric acid & C6H8O7 & 1,73 & & 191,01918 & 173,0082 & 129,0182 & 111,0075 & 87,0073 & 85,0280 \\
\hline 11 & Leucine and Isoleucine & $\mathrm{C} 6 \mathrm{H} 13 \mathrm{NO} 2$ & 1,84 & 132,10246 & & 86,0970 & 69,0706 & & & \\
\hline 12 & Tyrosine & $\mathrm{C} 9 \mathrm{H} 11 \mathrm{NO} 3$ & 1,93 & 182,08172 & & 165,0548 & 147,0443 & 136,0759 & 123,0444 & 119,0495 \\
\hline 13 & Phenylalanine & $\mathrm{C} 9 \mathrm{H} 11 \mathrm{NO} 2$ & 3,64 & 166,08681 & & 149,0598 & 131,0495 & 120,0811 & 107,0496 & 103,0547 \\
\hline 14 & Tryptophan & $\mathrm{C} 11 \mathrm{H} 12 \mathrm{~N} 2 \mathrm{O} 2$ & 9,38 & 205,09771 & & 188,0709 & 170,0602 & 159,0919 & 146,0602 & 118,0655 \\
\hline 15 & $\begin{array}{l}\text { Neochlorogenic acid (5-O- } \\
\text { Caffeoylquinic acid) }\end{array}$ & $\mathrm{C} 16 \mathrm{H} 1809$ & 10,14 & & 353,08726 & 191,0557 & 179,0344 & 173,0448 & 135,0441 & \\
\hline 16 & Salicylic acid-2-O-glucoside & $\mathrm{C} 13 \mathrm{H} 1608$ & 13,56 & & 299,07670 & 137,0234 & 113,0229 & 93,0331 & 85,0280 & 71,0123 \\
\hline 17 & $\begin{array}{l}\text { Chlorogenic acid (3-O- } \\
\text { Caffeoylquinic acid) }\end{array}$ & $\mathrm{C} 16 \mathrm{H} 1809$ & 14,83 & & 353,08726 & 191,0556 & 179,0344 & 173,0443 & 161,0234 & 135,0441 \\
\hline 18 & $\begin{array}{l}\text { Chryptochlorogenic acid (4-0- } \\
\text { Caffeoylquinic acid) }\end{array}$ & $\mathrm{C} 16 \mathrm{H} 1809$ & 16,11 & & 353,08726 & 191,0555 & 179,0344 & 173,0447 & 161,0232 & 135,0441 \\
\hline 19 & 4-0-(4-Coumaroyl)quinic acid & $\mathrm{C} 16 \mathrm{H} 1808$ & 16,14 & & 337,09235 & 191,0555 & 173,0447 & 163,0390 & 119,0489 & 93,0331 \\
\hline 20 & Vanillin & $\mathrm{C} 8 \mathrm{H} 8 \mathrm{O} 3$ & 16,22 & 153,05517 & & 125,0600 & 111,0445 & 110,0366 & 93,0341 & 65,0393 \\
\hline 21 & 5-O-(4-Coumaroyl)quinic acid & C16H1808 & 17,38 & & 337,09235 & 191,0556 & 173,0447 & 163,0391 & 119,0490 & 93,0332 \\
\hline 22 & Indole-3-acetic acid & $\mathrm{C} 10 \mathrm{H} 9 \mathrm{NO} 2$ & 17,98 & & 174,05551 & 146,0601 & 144,0440 & 130,0651 & 128,0492 & \\
\hline 23 & $\begin{array}{l}\text { 4-0-(4-Coumaroyl)quinic acid cis } \\
\text { isomer }\end{array}$ & $\mathrm{C} 16 \mathrm{H} 1808$ & 18,04 & & 337,09235 & 191,0556 & 173,0447 & 163,0391 & 119,0489 & 93,0331 \\
\hline
\end{tabular}




\begin{tabular}{|c|c|c|c|c|c|c|c|c|c|c|}
\hline 24 & $\begin{array}{l}\text { Isoscopoletin (6-Hydroxy-7- } \\
\text { methoxycoumarin) }\end{array}$ & $\mathrm{C} 10 \mathrm{H} 8 \mathrm{O} 4$ & 18,33 & 193,05009 & & 178,0264 & 165,0550 & 149,0598 & 137,0600 & 133,0287 \\
\hline & 5-O-Feruloylquinic acid & C17H20O9 & 18,42 & & 367,10291 & 193,0503 & 191,0556 & 173,0447 & 134,0362 & 93,0331 \\
\hline & Riboflavin & C17H2ON4O6 & 19,03 & 377,14611 & & 359,1352 & 243,0879 & 200,0824 & 172,0872 & 69,0342 \\
\hline & $\begin{array}{l}\text { Scopoletin (7-Hydroxy-6- } \\
\text { methoxycoumarin) }\end{array}$ & $\mathrm{C} 10 \mathrm{H} 804$ & 19,08 & 193,05009 & & 178,0263 & 165,0546 & 149,0597 & 137,0601 & 133,0287 \\
\hline & $\begin{array}{l}\text { Azelaamic acid (9-Amino-9- } \\
\text { oxononanoic acid) }\end{array}$ & $\mathrm{C} 9 \mathrm{H} 17 \mathrm{NO} 3$ & 19,21 & & 186,11302 & 125,0959 & 97,0647 & & & \\
\hline & 6-Methylcoumarin & $\mathrm{C} 10 \mathrm{H} 8 \mathrm{O} 2$ & 19,44 & 161,06026 & & 133,0651 & 115,0547 & 105,0704 & 91,0547 & 79,0549 \\
\hline 0 & 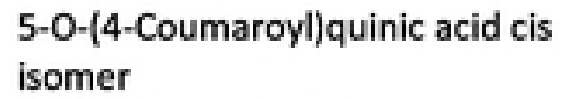 & $\mathrm{C} 16 \mathrm{H} 1808$ & 19,63 & & 337,09235 & 191,0555 & 173,0446 & 163,0390 & 119,0491 & 93,0330 \\
\hline 1 & Indole-4-carbaldehyde & $\mathrm{C} 9 \mathrm{H} 7 \mathrm{NO}$ & 19,67 & 146,06059 & & 118,0655 & 117,0574 & 91,0548 & & \\
\hline 32 & Fraxidin vagy Isofraxidin & $\mathrm{C} 11 \mathrm{H} 1005$ & 19,72 & & 221,04500 & 206,0219 & 190,9983 & 163,0030 & & \\
\hline 33 & $\begin{array}{l}\text { Loliolide } \\
\text { 4-Hydroxy-3- }\end{array}$ & $\mathrm{C} 11 \mathrm{H} 16 \mathrm{O} 3$ & 20,05 & 197,11777 & & 179,1069 & 161,0962 & 135,1171 & 133,1015 & 107,0860 \\
\hline 4 & $\begin{array}{l}\text { methoxycinnamaldehyde } \\
\text { (Coniferyl aldehyde) }\end{array}$ & $\mathrm{C} 10 \mathrm{H} 10 \mathrm{O} 3$ & 20,59 & 179,07082 & & 161,0599 & 147,0442 & 133,0652 & 119,0495 & 55,0186 \\
\hline 5 & 7-Deoxyloganic acid isomer & $\mathrm{C} 16 \mathrm{H} 2409$ & 22,36 & & 359,13421 & 197,0815 & 153,0909 & 135,0805 & 109,0643 & 89,0230 \\
\hline & $\begin{array}{l}\text { Di-O-caffeoylquinic acid isomer } \\
1\end{array}$ & $\mathrm{C} 25 \mathrm{H} 24012$ & 22,61 & & 515,11896 & 353,0884 & 191,0556 & 179,0342 & 173,0447 & 135,0441 \\
\hline 7 & $\begin{array}{l}\text { Di-O-caffeoylquinic acid isomer } \\
2\end{array}$ & $\mathrm{C} 25 \mathrm{H} 24012$ & 22,77 & & 515,11896 & 353,0884 & 191,0556 & 179,0342 & 173,0446 & 135,0440 \\
\hline 3 & $\begin{array}{l}\text { Salvianolic acid derivative } \\
\text { isomer } 1\end{array}$ & $\mathrm{C} 27 \mathrm{H} 22 \mathrm{O} 12$ & 22,80 & & 537,10331 & 375,0705 & 201,0165 & 179,0343 & 161,0234 & 135,0440 \\
\hline 9 & $\begin{array}{l}\text { Butein }\left(2^{\prime}, 3,4,4^{\prime}-\right. \\
\text { Tetrahydroxychalcone) }\end{array}$ & $\mathrm{C} 15 \mathrm{H} 12 \mathrm{O} 5$ & 23,00 & 273,07630 & & 255,0656 & 227,0699 & 209,0602 & 163,0391 & 137,0235 \\
\hline 0 & Quercetin-3-O-glucuronide & $\mathrm{C} 21 \mathrm{H} 18013$ & 23,26 & & 477,06692 & 301,0359 & 178,9980 & 163,0028 & 151,0026 & 121,0281 \\
\hline 1 & $\begin{array}{l}\text { Isoquercitrin (Hirsutrin, } \\
\text { Quercetin-3-O-glucoside) }\end{array}$ & $\mathrm{C} 21 \mathrm{H} 20 \mathrm{O} 12$ & 23,47 & & 463,08765 & 301,0358 & 300,0283 & 271,0253 & 255,0300 & \\
\hline & Chrysoeriol-O-glucoside & $\mathrm{C} 22 \mathrm{H} 22 \mathrm{O} 11$ & 23,87 & & 461,10839 & 299,0560 & 298,0484 & 270,0537 & 255,0292 & 227,0346 \\
\hline & $\begin{array}{l}\text { Salvianolic acid derivative } \\
\text { isomer } 2\end{array}$ & $\mathrm{C} 27 \mathrm{H} 22 \mathrm{O} 12$ & 24,60 & & 537,10331 & 375,0705 & 201,0166 & 179,0343 & 161,0236 & 135,0440 \\
\hline
\end{tabular}




\begin{tabular}{|c|c|c|c|c|c|c|c|c|c|c|}
\hline 44 & $\begin{array}{l}\text { Di-O-caffeoylquinic acid isomer } \\
3\end{array}$ & $\mathrm{C} 25 \mathrm{H} 24 \mathrm{O} 12$ & 24,62 & & 515,11896 & 353,0884 & 191,0557 & 179,0342 & 173,0447 & 135,0440 \\
\hline 45 & Azelaic acid & $\mathrm{C9H} 1604$ & 25,05 & & 187,09704 & 169,0863 & 143,1070 & 125,0959 & 123,0803 & \\
\hline 46 & Kaempferol-3-O-glucuronide & $\mathrm{C} 21 \mathrm{H} 18 \mathrm{O} 12$ & 25,18 & & 461,07200 & 285,0410 & 229,0505 & 113,0231 & & \\
\hline 47 & Apigenin-O-malonylglucoside & $\mathrm{C} 24 \mathrm{H} 22 \mathrm{O} 13$ & 25,21 & & 517,09822 & 473,1116 & 269,0461 & 268,0376 & & \\
\hline 48 & $\begin{array}{l}\text { Astragalin (Kaempferol-3-O- } \\
\text { glucoside) }\end{array}$ & $\mathrm{C} 21 \mathrm{H} 20 \mathrm{O} 11$ & 25,26 & & 447,09274 & 285,0410 & 284,0331 & 255,0302 & 227,0350 & \\
\hline 49 & Isorhamnetin-3-O-glucoside & $\mathrm{C} 22 \mathrm{H} 22 \mathrm{O} 12$ & 25,48 & & 477,10330 & 315,0524 & 314,0437 & 285,0406 & 271,0248 & 243,0292 \\
\hline 50 & $\begin{array}{l}\text { Kukulkanin B (3'-Methoxy- } \\
2^{\prime}, 4,4^{\prime} \text {-methoxychalcone) }\end{array}$ & $\mathrm{C} 16 \mathrm{H} 1405$ & 25,50 & 287,09195 & & 269,0810 & 241,0864 & 177,0548 & 145,0286 & 137,0235 \\
\hline 51 & Isorhamnetin-3-O-glucuronide & $\mathrm{C} 22 \mathrm{H} 20 \mathrm{O} 13$ & 25,70 & & 491,08257 & 315,0517 & 300,0275 & 271,0249 & & \\
\hline 52 & Dihydroactinidiolide & $\mathrm{C} 11 \mathrm{H} 16 \mathrm{O} 2$ & 27,16 & 181,12286 & & 163,1119 & 145,1014 & 135,1171 & 121,1015 & 107,0860 \\
\hline 53 & Dimethoxy-tetrahydroxyflavone & C17H14O8 & 28,38 & & 345,06105 & 330,0386 & 315,0153 & 287,0204 & 215,0347 & 178,9978 \\
\hline 54 & Dihydroxy-methoxyflavone & $\mathrm{C} 16 \mathrm{H} 12 \mathrm{O} 5$ & 29,89 & & 283,06065 & 268,0381 & 267,0305 & 240,0427 & 239,0350 & 211,0396 \\
\hline 55 & $\begin{array}{l}\text { Dimethoxy-trihydroxyflavone } \\
\text { isomer } 1\end{array}$ & C17H14O7 & 30,09 & & 329,06613 & 314,0439 & 299,0197 & 283,0869 & 271,0247 & 255,0913 \\
\hline 56 & Trihydroxy-trimethoxyflavone & $\mathrm{C} 18 \mathrm{H} 1608$ & 30,36 & & 359,07670 & 344,0541 & 329,0307 & 314,0075 & 301,0358 & 286,0129 \\
\hline 57 & $\begin{array}{l}\text { Dimethoxy-trihydroxyflavone } \\
\text { isomer } 2\end{array}$ & C17H14O7 & 30,38 & & 329,06613 & 314,0439 & 299,0201 & 283,0871 & 271,0252 & 253,0763 \\
\hline 58 & $\begin{array}{l}\text { Liquiritigenin }\left(4^{\prime}, 7-\right. \\
\text { Dihydroxyflavanone) }\end{array}$ & $\mathrm{C} 15 \mathrm{H} 12 \mathrm{O} 4$ & 30,56 & & 255,06574 & 153,0183 & 135,0077 & 119,0489 & 91,0175 & \\
\hline 59 & $\begin{array}{l}\text { Hymenoxin (5,7,Dihydroxy- } \\
3^{\prime}, 4^{\prime}, 6,8 \text {-tetramethoxyflavone) }\end{array}$ & $\mathrm{C} 19 \mathrm{H} 1808$ & 32,11 & 375,10800 & & 360,0840 & 345,0606 & 342,0736 & 330,0367 & 317,0659 \\
\hline 60 & Epiafzelechin trimethyl ether & $\mathrm{C} 18 \mathrm{H} 2005$ & 33,32 & 317,13890 & & 167,0704 & 163,0755 & 155,0705 & 137,0598 & 121,0651 \\
\hline 61 & $\begin{array}{l}\text { Nevadensin (5,7-Dihydroxy- } \\
4^{\prime}, 6,8 \text {-trimethoxyflavone) }\end{array}$ & $\mathrm{C} 18 \mathrm{H} 1607$ & 33,91 & 345,09743 & & 330,0736 & 315,0501 & 312,0631 & 287,0554 & \\
\hline
\end{tabular}

